\title{
Distribution pattern of an expanding Osprey (Pandion haliaetus) population in a changing environment
}

\author{
Mei-Ling Bai · Daniel Schmidt • Eckhard Gottschalk • \\ Michael Mühlenberg
}

Received: 3 December 2007/Revised: 15 September 2008/ Accepted: 22 September 2008/Published online: 21 October 2008 (C) The Author(s) 2008. This article is published with open access at Springerlink.com

\begin{abstract}
We studied the nest site selection and distribution pattern at landscape level of the German Osprey population, and demonstrated how to test the predictions of the ideal free distribution theory and its derivatives on such an expanding population. Information about the location and breeding success of each Osprey nest site between 1995 and 2005 was collected through a longterm monitoring programme. Data of land cover types were acquired from the administrations of each federal state and the CORINE Land Cover database. The results showed that Ospreys preferred landscapes with more water bodies and forests. Such sites were also occupied earlier and had higher local population density. However, in the study period of 11 years, there was a gradual shift from forest-dominated landscapes to agricultural landdominated landscapes. The breeding success increased over time, with no difference in the breeding success between pairs nesting on trees and poles, whereas there was higher breeding success at nest sites surrounded by more agricultural land and less forest. The more efficient foraging in eutrophic lakes in agricultural landscapes was the most likely cause for the higher breeding success. The distribution pattern of the Ospreys did not match the resource allocation, which deviated from the models
\end{abstract}

Communicated by F. Bairlein.

M.-L. Bai $(\bowtie)$ · E. Gottschalk · M. Mühlenberg

Centre for Nature Conservation, Göttingen University,

Göttingen, Germany

e-mail: mbai@gate.sinica.edu.tw; mbai@gwdg.de

D. Schmidt

NABU-Vogelschutzzentrum Mössingen, Ziegelhütte 21,

72116 Mössingen, Germany tested. We suggested that the proximate cues used for nest site selection mismatched site quality due to anthropogenic environmental changes.

Keywords Osprey · Pandion haliaetus .

Ideal free distribution - Ideal despotic distribution .

Ideal preemption

\section{Introduction}

Understanding the patterns of species distribution in heterogeneous habitats is a fundamental issue in ecology. Representing an evolutionarily stable strategy, the ideal free distribution (IFD) theory (Fretwell and Lucas 1970) and its derivative or modified forms (e.g. Fretwell 1972; Parker and Sutherland 1986; Morris 1987, 1988; Pulliam and Danielson 1991; Flaxman and Reeve 2006) provide mechanistic explanations for the distribution of animals. They further link the habitat choice of individuals with the density- or site-dependent regulation of populations (Rodenhouse et al. 1997; Krüger and Lindström 2001; McPeek et al. 2001; Morris 2003).

In the IFD model, it is assumed that individuals are equal in their competitive ability, have adequate information about patch quality, and are free to move and seek out patches where they may realise the highest fitness. The distribution of individuals should therefore reflect patch quality, which is assumed as an integrated function of its basic quality and density of competitors. Based on the IFD model, several predictions can be made: (1) sites with higher basic quality are occupied earlier (H1); (2) when population size fluctuates, sites with higher basic quality are occupied more frequently (H2); (3) at any given time, density is higher at sites with higher basic quality (H3); and 
(4) at any given time, the fitness of individuals is equal across different sites (H4a).

The ideal despotic distribution (IDD) model is a modification of the IFD which takes the inequalities in competitive abilities into account (Fretwell and Lucas 1970; Fretwell 1972). For a population following the IDD, the above predictions $\mathrm{H} 1, \mathrm{H} 2$ and $\mathrm{H} 3$ from the IFD still hold, but the IDD predicts higher fitness at sites with higher basic quality (H4b), because dominant individuals prevent local density from becoming so high as to greatly depress their fitness. Consequently, higher fitness will also be observed at earlier occupied sites (H4c) (Fretwell 1972; Morris 2003; Sergio et al. 2007).

The ideal preemptive distribution (IPD) suggested by Pulliam and Danielson (1991) is a further variant considering a different mode of resource acquisition. In the IPD model, sites are defined as definite areas of exclusive occupancy, thus the quality of a site is independent from local density. Within the IPD model, the above predictions $\mathrm{H} 1$ and $\mathrm{H} 2$ still hold, but $\mathrm{H} 3$ does not apply as the IPD operates in a density-free manner. It also predicts, like the IDD, higher fitness at better sites (H4b) and higher fitness at earlier occupied sites (H4c) (Rodenhouse et al. 1997; Pöysä et al. 1998; Sergio et al. 2007).

The IFD and its derivative theories can also be applied to a population expanding geographically, but this potential has not been well explored. Lohmus (2001a) investigated the habitat selection of a recovering Osprey (Pandion haliaetus) population in Estonia, and Soutullo et al. (2006) studied the fecundity and distribution pattern of an expanding Montagu's Harrier (Circus pygargus) population in Spain. Both studies examined the trend of fitness measurements following the increasing density or the sequential site occupation of the growing population as a test of the distribution models. However, when a population is expanding geographically, intrinsic correlation between space and time exists in such a process, and the predictions of the distribution models have to be rephrased. Sites closer to the source population usually have a higher probability of being occupied earlier. The H1 should therefore be modified to: at a given distance from the source population, sites with higher basic quality are occupied earlier $\left(\mathrm{H}^{\prime}\right)$. Within a specific observation period, a site being occupied earlier will also be occupied more frequently simply by chance. The proper form of the $\mathrm{H} 2$ should thus be: among the sites that started being occupied at the same time, sites with higher basic quality are occupied more frequently $\left(\mathrm{H}^{\prime}\right)$. The further away a site is, the higher the probability of it being under-saturated. Local density thus tends to be higher at sites closer to the source, regardless of site quality. The $\mathrm{H} 3$ should therefore be restrained to: at a given distance from the source population, density is higher at sites with higher basic quality at any given time ( $\left.\mathrm{H}^{\prime}\right)$.
When analysing breeding performance of an expanding population, one further consideration should be taken into account. In many cases, the founders may face low breeding success in the beginning phase of establishment. This is often true when these dispersers are younger individuals, which may be less attractive to mates, lack experience or be bound by physiological constraints (Lohmus 2001b; Bunce et al. 2005). Alternatively, the founders may benefit from the extremely low density of competitors and have higher breeding success. These factors are independent of site quality. Thus, the equilibrium phase in which the breeding success is independent from the site age has first to be identified, and the comparison of breeding success among sites should only be examined in this phase.

When studying an expanding population, all the above confounding factors should be taken into account if the habitat selection and distribution pattern are to be properly interpreted. In this study, we demonstrate how to test these predictions using the expanding Osprey population of Germany (Schmidt 2001, 2004). The nest site selection and distribution pattern of this population was investigated at landscape level. We examined the landscape patterns of earlier occupied sites, more frequently occupied sites and sites with higher local density, and investigated their relationships with breeding success.

\section{Methods}

\section{Population data}

The Osprey, usually regarded as the only species of its own family, Pandionidae, was once a widespread breeding species in Germany (Schmidt 1995a). Extinctions over large areas due to human persecution occurred in the late 1800s and early 1900s. In the 1960s, the extensive use of persistent organochlorine pesticides, such as DDT, further caused a worldwide population crash (Poole 1989). The last breeding Osprey in the former West Germany vanished in 1963, while a diminished eastern population persisted. Since the mid-1970s, the ban on pesticides (Weber et al. 2003) and hunting led to the population's recovery. This was reflected both in its increasing population density and expanding spatial distribution (Schmidt 2001, 2004).

An extensive colour-ringing programme on the Osprey has been carried out in Germany since 1995 (Schmidt 1995b). Occupied nest sites were located and monitored by local nest guardians, and nestlings were ringed by regional ringers, mostly at between 28 and 35 days old. This study was based on the reports of regional coordinators and ringers, including 3,142 breeding attempts at 720 different nest sites from 1995 to 2005 . These nest sites were situated 
within the federal states of Mecklenburg-Vorpommern, Brandenburg, Sachsen, Sachsen-Anhalt and Niedersachsen. In Mecklenburg-Vorpommern, the records before 2003 were incomplete, as they also were in some areas of Brandenburg before 2001. These data were then used only to represent ever-used sites in the analysis of habitat selection, but not in other parts of the analysis. A total of 474 sites, which included 2,232 breeding attempts, were considered under reasonably consistent control.

Variables acquired direct from ringers and coordinators included the coordinates, substrate type, year of first occupation, site occupancy and annual reproductive output of each nest site. Coordinates were obtained either from GPS readings or detailed local maps. Substrate type referred to the structure on which the nest was built, and was grouped into trees or poles. The latter were mainly pylons, but also included lampposts, concrete poles and wooden constructions originally built for hosting White Storks (Ciconia ciconia). Year of first occupation was treated as unknown for nests established before 1995. Site occupancy was defined as the number of years occupied between 1995 and 2005. Reproductive output was recorded as the number of ringed nestlings. As breeding performance of the Osprey may fluctuate year to year due to climate (Solonen 2008) or other factors, we calculated the relative breeding success as "number of nestlings of the nest - average number of nestlings of all occupied nests in the year." This was to standardise reproductive output by annual mean, so that the fluctuation between years could be adjusted.

The dataset was then incorporated into the geographic information system ArcGIS to extract spatial attributes. We used the KERNEL function to interpolate a density surface from all known occupied nest sites in 1995. The area of highest $10 \%$ density was selected and defined as "source." Then, for each nest site, the distance to source was calculated and used as an index of the distance to source population. The nearest neighbour distance was also calculated for each site in each year as an index of local density.

\section{Land cover data}

Digitised coverage of water bodies was acquired from the administrations of each federal state. Other land cover types were derived from the CORINE Land Cover database (Umweltbundesamt 2004). The land cover types considered in this study included water (subdivided into river and lake), forest (coniferous, mixed and broadleaved), agricultural land (arable and pasture) and settlement (city and industry).

At each nest site, neighbourhoods of radius 2, 4, 7 and $10 \mathrm{~km}$ were constructed with ArcGIS. The area of each land cover type was calculated in each zone (Table 1). The selection of these distance criteria was based on the results of a telemetry study within the region (Schmidt 1999). The water bodies visited by breeding Ospreys were located 2.7$7 \mathrm{~km}$ from the nest sites. Water bodies within $4.3 \mathrm{~km}$ of the nests were most frequently used. This telemetry study was conducted in an area with an especially high density of water bodies. Therefore, although foraging trips over $7 \mathrm{~km}$ were considered rare, one further zone $(10 \mathrm{~km})$ was added in the analysis to cover the possible condition of other areas, as well as to test the role of land cover types on a larger scale.
Table 1 Abbreviations and descriptions of landscape variables used in the analysis of Osprey (Pandion haliaetus) nest sites

\begin{tabular}{ll}
\hline Variables & Description \\
\hline D_Wat & Distance $(\mathrm{km})$ to nearest water bodies \\
D_Wat1 & Distance $(\mathrm{km})$ to nearest water bodies of area $>1$ ha \\
D_Wat10 & Distance $(\mathrm{km})$ to nearest water bodies of area $>10$ ha \\
D_Wat100 & Distance $(\mathrm{km})$ to nearest water bodies of area $>100$ ha \\
Water_2 $(4,7,10)$ & Area (ha) of water body within $2(4,7,10) \mathrm{km}$ radius \\
Lake_2 $(4,7,10)$ & Area (ha) of lake within $2(4,7,10) \mathrm{km}$ radius \\
River_2 $(4,7,10)$ & Area (ha) of river within $2(4,7,10) \mathrm{km}$ radius \\
Forest_2 $(4,7,10)$ & Area (ha) of forest within $2(4,7,10) \mathrm{km}$ radius \\
Conifer_2 $(4,7,10)$ & Area (ha) of coniferous forest within $2(4,7,10) \mathrm{km}$ radius \\
Mixed_2 $(4,7,10)$ & Area (ha) of mixed forest within $2(4,7,10) \mathrm{km}$ radius \\
Broadleaf_2 $(4,7,10)$ & Area (ha) of broadleaved forest within $2(4,7,10) \mathrm{km}$ radius \\
Agriculture_2 $(4,7,10)$ & Area (ha) of agricultural use within $2(4,7,10) \mathrm{km}$ radius \\
Arable_2 $(4,7,10)$ & Area (ha) of arable land within $2(4,7,10) \mathrm{km}$ radius \\
Pasture_2 $(4,7,10)$ & Area (ha) of pasture within $2(4,7,10) \mathrm{km}$ radius \\
Settlement _2 $(4,7,10)$ & Area (ha) of settlement within $2(4,7,10) \mathrm{km}$ radius \\
City_2 $(4,7,10)$ & Area (ha) of city and housing site within $2(4,7,10) \mathrm{km}$ radius \\
Industry_2 $(4,7,10)$ & Area (ha) of industrial use within $2(4,7,10) \mathrm{km}$ radius \\
\hline
\end{tabular}


Water bodies are the only foraging sites for the Osprey, a species entirely feeding on fish. In addition to the total area of water body surrounding a site, the importance of the area of each water body and the proximity to the water body have also been addressed (Ewins 1997; Lohmus 2001a). Thus, the distances to a water body, to a water body of area $>1$ ha, to a water body of area $>10$ ha and to a water body of area $>100$ ha were calculated for each site.

\section{Statistical analysis}

To study the nest site preference, 720 random points were selected and the same set of landscape variables was generated for each point. As the distribution of pylons or proper nesting trees was not available, random points were used instead of potentially available nesting substrates. Pylons are abundant and widespread in the study area, and they are not bound to certain land cover types as are trees. Nevertheless, the results might reflect the effect of both the landscape preference of the Osprey and the availability of nesting substrates.

Nest sites and random points had very distinct spatial distributions: the former were much more condensed around the source, as an intrinsic property of dispersal. To separate the real habitat selection from the effect of dispersal process, we used ANCOVA to compare each landscape variable between nest sites and random points, with the distance to source as covariate. Discriminant analysis with stepwise selection was applied to select the variable set which could best tell the nest sites from random points. We used half of the data for building the model, and the other half for validation.

To study the factors influencing the year of first occupation, site occupancy and nearest neighbour distance, we first examined their relationship with potentially confounding variables with correlation analysis. Partial correlation was then adopted to examine the effect of landscape variables, with the confounding variables controlled. ANCOVA was applied to test the effect of substrate type.

As for breeding success, we first examined the relationship between relative breeding success and site age, i.e. number of years since establishment. We identified the beginning phase, in which the relative breeding success and site age were correlated, and the equilibrium phase, in which the relative breeding success was independent of site age. Only the latter subset of data was used to test the relationships between landscape variables, year of first occupation, nearest neighbour distance and breeding success. General linear model (GLM) was applied to test the effects and deal with pseudoreplication. All statistics were conducted with SAS/STAT (SAS Institute 1999).

\section{Results}

Habitat selection

Compared to random points, the nest sites of Ospreys were located closer to water bodies of all sizes (Table 2). Correspondingly, there were more water bodies, mainly lakes, surrounding the nest sites. The nest sites also had more forest around, especially conifers. Landscapes with a higher proportion of agricultural land and settlement were unfavourable.

The variable set selected by discriminant analysis is shown in Table 3. The accuracy of the model was $80.3 \%$ in reclassification and $79.2 \%$ while testing with the independent testing dataset. Besides the predominant effect of the distance to source, water-related variables (distance to nearest water bodies of area $>10$ ha, area of lake within $10 \mathrm{~km}$ radius, area of water body within $2 \mathrm{~km}$ radius) accounted for three of the five land cover type variables in the model. The coverage of coniferous forest was selected into the model at the larger scale $(10 \mathrm{~km})$, while the area of city in the vicinity $(2 \mathrm{~km})$ was presented.

Table 2 The mean of each variable at nest sites and at random points, and the result of ANCOVA with the distance to source as covariate. Zones of different radius gave rise to same patterns, thus here only the results from the zone of radius $7 \mathrm{~km}$ are presented

\begin{tabular}{lrcc}
\hline Variables & \multicolumn{2}{l}{ Mean } & $P$ \\
\cline { 2 - 3 } & Nest site & Random point & \\
\hline D_Wat (km) & 0.8 & 1.5 & $* *$ \\
D_Wat1 (km) & 1.3 & 2.7 & $* * *$ \\
D_Wat10 (km) & 2.0 & 4.7 & $* * *$ \\
D_Wat100 (km) & 3.6 & 8.4 & $* * *$ \\
Water_7 (ha) & 906.6 & 300.7 & $* * *$ \\
Lake_7 (ha) & 869.3 & 234.4 & $* * *$ \\
River_7 (ha) & 36.9 & 65.8 & - \\
Forest_7 (ha) & $6,228.7$ & $3,731.0$ & $* * *$ \\
Conifer_7 (ha) & $4,932.0$ & $2,615.0$ & $* * *$ \\
Mixed_7 (ha) & 435.7 & 390.4 & - \\
Broadleaf_7 (ha) & 861.0 & 725.6 & $* *$ \\
Agriculture_7 (ha) & $7,249.7$ & $9,783.9$ & $* * *$ \\
Arable_7 (ha) & $5,921.5$ & $7,941.8$ & $* * *$ \\
Pasture_7 (ha) & $1,328.3$ & $1,842.1$ & $* *$ \\
Settlement 77 (ha) & 564.7 & 964.7 & $* * *$ \\
City_7 (ha) & 455.9 & 811.9 & $* * *$ \\
Industry_7 (ha) & 108.8 & 152.8 & - \\
\hline$* P<0.05$ & & & \\
$* * P<0.01$ & & & \\
$* * * P<0.001$ & & &
\end{tabular}


Table 3 Variables selected by the discriminant analysis between nest sites and random sites

\begin{tabular}{llrl}
\hline Variables in the model & $R^{2}$ & $F$ & $P$ \\
\hline Distance to source & 0.279 & 278.3 & $<0.0001$ \\
D_Wat10 & 0.094 & 74.4 & $<0.0001$ \\
Conifer_10 & 0.057 & 42.9 & $<0.0001$ \\
City_2 & 0.014 & 10.3 & $<0.01$ \\
Lake_10 & 0.012 & 8.5 & $<0.01$ \\
Water_2 & 0.011 & 8.1 & $<0.01$ \\
\hline
\end{tabular}

\section{Year of first occupation}

As expected, the year of first occupation was significantly correlated with the distance to source $(r=0.21$, $P<0.001)$. The partial correlation coefficients between the year of first occupation and landscape variables under the control of distance to source are shown in Table 4 . Positive values indicated that the increase of the specific landscape variable corresponded to a larger number of years, i.e. the later occupation of a site. Forest and agricultural components in the landscape were most strongly correlated with the year of first occupation. Sites with more forest and less agricultural land in the surrounding area were occupied earlier. Water-related variables played minor roles. Only more water bodies within a $2-\mathrm{km}$ radius favoured earlier occupation. These relationships remained when two substrate types were considered separately.

The gradual expansion towards open landscapes could also be shown by the average proportion of forest and agricultural area around all occupied nest sites each year (Fig. 1). There was a trend of decreasing mean forest area $(r=-0.99, P<0.001)$ and increasing mean agricultural area $(r=0.99, P<0.001)$ across the study period.

Trees tended to be used earlier than poles under the control of distance to source (ANCOVA, $F=4.24$, $d f=1, P<0.05$ ), but this phenomenon was confounded by the covariate of land cover types, as a nest tree was more likely to have more forest area around it. The effect of substrate type diminished when any forest area or agricultural area variable was controlled (ANCOVA, $P>0.05$ in all tests).

\section{Site occupancy}

As expected, the number of years occupied was strongly correlated with the year of first occupation $(r=-0.65$, $P<0.001)$. When the year of first occupation was controlled, no landscape variable was related to the number of years occupied (partial correlation, $P>0.05$ in all tests). Nests on poles were occupied more frequently than nests on trees (ANCOVA, $F=5.42, d f=1, P<0.05$ ). Within each substrate type, there was still no significant relationship
Table 4 The partial correlation coefficients between landscape variables and (a) the year of first occupation and (b) the nearest neighbour distance, under the control of the distance to source

$* P<0.05$

$* * P<0.01$

$* * * P<0.001$

\begin{tabular}{|c|c|c|c|c|}
\hline & \multirow[t]{2}{*}{ (a) Year of first occupation } & \multicolumn{3}{|c|}{ (b) Nearest neighbour distance } \\
\hline & & All & Pole & Tree \\
\hline D_Wat & 0.039 & $0.055 * *$ & $0.088 * * *$ & 0.076 \\
\hline D_Wat1 & 0.015 & $0.064 * *$ & $0.090 * * *$ & $0.232 * * *$ \\
\hline D_Wat10 & 0.013 & $0.165 * * *$ & 0.038 & $0.498 * * *$ \\
\hline D_Wat100 & -0.051 & $0.216 * * *$ & -0.016 & $0.436 * * *$ \\
\hline Water_2 & $-0.137 *$ & -0.033 & -0.003 & $-0.144 * * *$ \\
\hline Water_4 & -0.079 & $-0.070 * * *$ & -0.035 & $-0.241 * * *$ \\
\hline Water_7 & -0.013 & $-0.093 * * *$ & -0.042 & $-0.277 * * *$ \\
\hline Water_10 & 0.010 & $-0.121 * * *$ & $-0.072 * *$ & $-0.290 * * *$ \\
\hline Forest_2 & $-0.194 * * *$ & $0.056 * *$ & $-0.187 * * *$ & 0.060 \\
\hline Forest_4 & $-0.209^{* * *}$ & 0.034 & $-0.176^{* * *}$ & -0.045 \\
\hline Forest_7 & $-0.251 * * *$ & -0.009 & $-0.166^{* * *}$ & $-0.142 * * *$ \\
\hline Forest_10 & $-0.262 * * *$ & -0.037 & $-0.158 * * *$ & $-0.201 * * *$ \\
\hline Agriculture_2 & $0.202 * * *$ & $-0.057 * *$ & $0.156^{* * *}$ & -0.032 \\
\hline Agriculture_4 & $0.199 * * *$ & -0.039 & $0.163 * * *$ & $0.135^{* *}$ \\
\hline Agriculture_7 & $0.202 * * *$ & 0.005 & $0.160 * * *$ & $0.241 * * *$ \\
\hline Agriculture_10 & $0.205^{* * *}$ & $0.046^{*}$ & $0.169 * * *$ & $0.275^{* * *}$ \\
\hline Settlement_2 & 0.056 & -0.017 & $0.073 * *$ & -0.009 \\
\hline Settlement_4 & 0.041 & -0.036 & $0.088 * * *$ & 0.054 \\
\hline Settlement_7 & 0.103 & -0.017 & $0.126 * * *$ & 0.056 \\
\hline Settlement_10 & $0.114 *$ & $-0.051 *$ & 0.046 & 0.032 \\
\hline
\end{tabular}




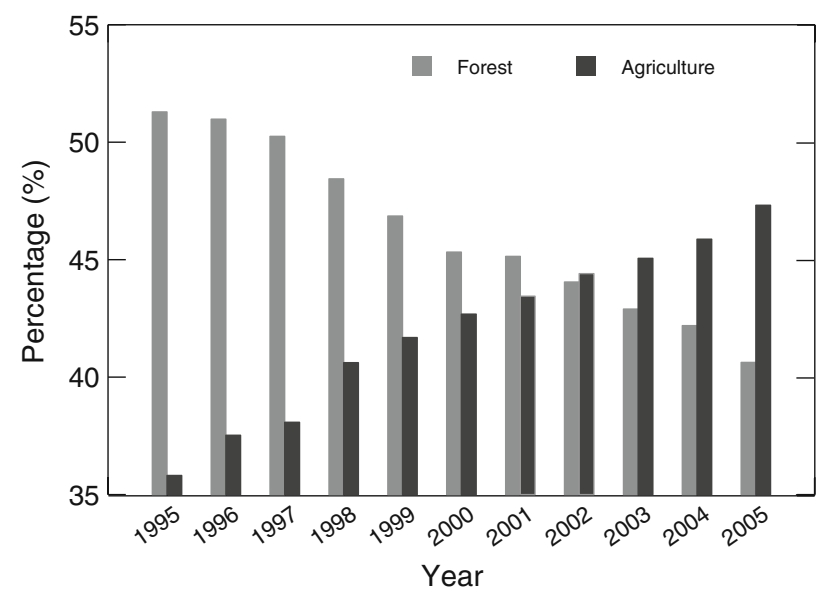

Fig. 1 The trends of mean forest area and mean agriculture area around Osprey (Pandion haliaetus) nest sites (as percentages within a $7-\mathrm{km}$ radius)

between any landscape variable and the number of years occupied (partial correlation, $P>0.05$ in all tests).

\section{Density}

The nearest neighbour distance was positively correlated with the distance to source $(r=0.30, P<0.001)$ and negatively correlated with year $(r=-0.05, P<0.05)$, corresponding to the lower density further from source and growing number over time of an expanding population. The relationships between nearest neighbour distance and landscape variables under the control of distance to source and year are shown in Table 4. Positive values indicated that the increase of the specific landscape variable corresponded to a greater nearest neighbour distance, i.e. lower local density. Higher density occurred in areas closer to water and surrounded by more water bodies. The effects of forest and agricultural land were obscured by the substrate type. Substrate type had great influence on local density (ANCOVA, $F=60.65, d f=1, P<0.001$ ), as poles allowed Ospreys to nest closer to each other. When treating the two types separately, higher Osprey density was related to more forest and less agricultural land in the surroundings for both substrate types (Table 4).

\section{Breeding success}

The relationship between the relative breeding success and the age of a site is shown in Fig. 2. In the first 3 years after establishment, the relative breeding success increased with site age (GLM, $F=44.07, d f=1, P<0.001$ ), but from the fourth year onwards, the breeding performance of a site became steady (GLM, $F=0.13, d f=1, \quad P=0.72$ ). Within this subset of data, breeding success was higher at nests surrounded by more agricultural land and less forest

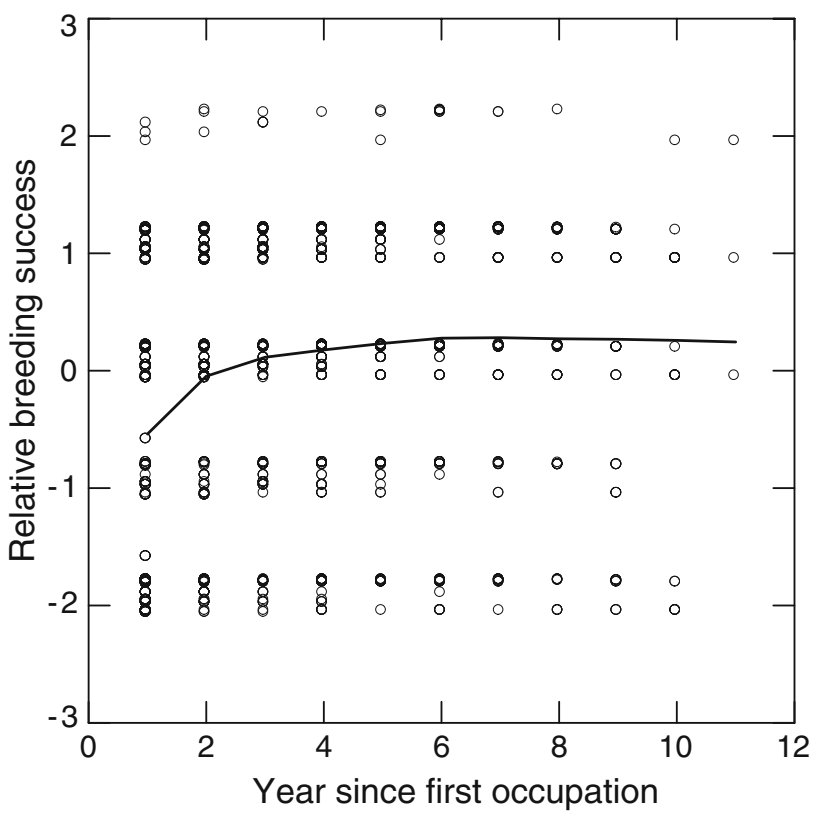

Fig. 2 The relationship between relative breeding success and the year since first occupation of nest sites. The curve was fitted with locally weighted least-squares (LOWESS) method

(GLM, $P<0.01$ in all tests). The distance to the nearest water body, the area of water body and the area of settlement around the nest site did not influence the breeding success (GLM, $P>0.05$ in all tests). Breeding success was not related to substrate type (GLM, $F=1.52, d f=1$, $P=0.22$ ), nearest neighbour distance (GLM, $F=0.62$, $d f=1, P=0.43)$ nor the year of first occupation (GLM, $F=1.68, d f=1, P=0.20$ ).

Similar relationships were indicated when observing the average breeding performance of the whole population over time. The mean brood size showed a positive trend across the study period (Spearman rank correlation, $r=0.94, P<0.001)$. Combined with the fact that the population expanded towards agricultural landscapes (Fig. 1), the mean brood size was negatively correlated with mean forest area (Spearman rank correlation, $r=$ $-0.94, P<0.001)$ and positively correlated with mean agricultural area (Spearman rank correlation, $r=0.94$, $P<0.001$ ) within a $7-\mathrm{km}$ radius around the nest sites.

\section{Discussion}

Nest site selection by the Osprey

In summary, Ospreys preferred to nest in areas with more lakes and forests, less agricultural land and less human settlement. Such areas also supported higher local densities, and were occupied earlier in the study period (Table 5). 
Table 5 Summary of the effects of landscape variables.

\begin{tabular}{lllll}
\hline & Water & Forest & Agriculture & Settlement \\
\hline Use of a site & + & + & - & - \\
Earlier used & $(+)$ & + & - & $(-)$ \\
More frequently used & $\mathrm{x}$ & $\mathrm{x}$ & $\mathrm{x}$ & $\mathrm{x}$ \\
Higher local density & + & + & - & $(-)$ \\
Higher breeding success & $\mathrm{x}$ & - & + & $\mathrm{x}$
\end{tabular}

+ Positive relationship, - negative relationship, $\mathrm{x}$ no relationship Parentheses indicate that the relationship is only significant in one of the several scales or for one substrate type

Water bodies, being the only foraging site for Ospreys, are the most important factor in their nest site selection. Water body composed about $5.9 \%$ of the area within a $7-\mathrm{km}$ radius of the nest site. This was low compared to $17.2 \%$ in a telemetry study in eastern Germany (Schmidt 1999). The Ospreys actually shape their home range to cover the main foraging areas, not as a circle centred on nest sites. The analysis in the current study was to indicate the landscape features around nest sites, but did not necessarily detail the resource to which they actually had access. The proximity to water in general increased the usage of a site, but the variables selected by discriminant analysis indicated the importance of larger water bodies (area $>10$ ha) over smaller ones. This was consistent with the observation of feeding flights (Lohmus 2001a).

The preference for forest landscape, especially conifers, might reflect the availability of suitable nesting substrates. In the study area, when Ospreys nest on trees, the Scots pine (Pinus sylvestris) is preferred (Schmidt 1999). However, availability could not provide the full explanation. For nests on poles, sites with more forest around were also occupied earlier and had a higher local density. The natal site fidelity of the Osprey (Schmidt et al. 2006) might relate to this phenomenon.

\section{Shifting distribution of the expanding population}

We found that the later-established Osprey nest sites were located in areas with less forest and more agricultural land around them. As time went on, therefore, the population as a whole expanded towards open landscape. This could not be explained by the increasing use of poles, as the same trends existed when nests on trees and poles were considered separately.

A traditional explanation for this phenomenon would be that the preferred patches (within forest) were mostly occupied, forcing the later settlers to the edge. However, the population might have been undergoing a reshaping of habitat selection, i.e. new preferences were being formed. The current work did not allow a judgement between the two alternatives, as so far there had been no decline in the forest population. But the shift of preference was very likely to happen, since the nests surrounded by more agricultural land had larger brood sizes. If the nest site selection of Osprey was caused by natal site fidelity or by the recognition of landscape pattern in the nestling stage, the preference for open landscape would spread within the population.

Breeding success and landscape pattern

Why did nests surrounded by more agricultural land have higher breeding success? A possible reason is the different quality of water bodies in different landscapes. Lakes in agricultural landscapes tend to be more eutrophic, as intensive agriculture is usually the primary source of nutrients in surface waters (Mehner et al. 2005; Ekholm and Mitikka 2006; Schindler et al. 2006). The higher productivity in eutrophic lakes has been related to the population increase of several waterfowl species (Suter 1995; Fernandez et al. 2005). Ospreys have also been found to fish more frequently and more efficiently in eutrophic, less transparent waters (Schmidt 1999; Lohmus 2001a). The higher breeding success in the agricultural landscape might therefore arise from higher resource availability. An alternative explanation is the difference in predation pressure. The potential predators of Osprey nestlings include Pine Marten (Martes martes), Goshawk (Accipiter gentilis) and Eagle Owl (Bubo bubo) (Lohmus 2001b; Odsjö and Sondell 2001), and the first two are more active in forests.

Although the presence of water bodies is the most important factor for Ospreys' nest site selection, neither the distance to water bodies nor the area of water bodies in the neighbourhood were related to their breeding success. The density of water bodies was high in the study area. Presumably, with the current population density, the breeding success of Ospreys was not suppressed by insufficient access to water bodies. The different fish abundance in each water body might further conceal the roles of the distance to water bodies and the area of water bodies in the neighbourhood.

We have shown that breeding success was not related to substrate type (tree or pole), in contrast to earlier findings (Meyburg et al. 1996). Our results mainly derived from counting the large nestlings in the nest when ringing them, a method with higher accuracy than counting them from the ground as Meyburg et al. (1996) had done.

\section{Distribution pattern of the Osprey}

If the Osprey population followed any of the ideal models, based on $\mathrm{H} 1$ and $\mathrm{H} 2$, the sites surrounded by more water bodies and more forest should have better quality. However, the breeding success was neither equal among sites as predicted by the IFD (H4a), nor higher at sites with more 
water bodies and forest around as suggested by the IDD and the IPD ( $\mathrm{H} 4 \mathrm{~b}$ and $\mathrm{H} 4 \mathrm{c}$ ). Breeding success was actually lower at sites surrounded by more forest (Table 5).

We also found no relationship between breeding success and the year of first occupation. In the study of Estonian Osprey populations, lower breeding success was observed for newcomers compared to earlier settlers (Lohmus 2001a), which was used as one piece of evidence supporting IDD. However, the author did not compare breeding success in the equilibrium phase. The lower breeding success in the beginning phase would therefore suppress the average breeding performance for the newcomers more than for the earlier settlers; thus, the observed pattern might occur independently of site quality.

Abrahams (1986) proposed the perception limit theory as an explanation of deviation from the ideal models. In this theory, the lack of information about habitat quality leads to a tendency towards random distribution of the animals. The animals, therefore, always under-match the resources, since poor habitats are over-exploited. For the Osprey population studied, the poor habitats were overexploited as suggested, but this was not caused by random distribution. In fact, the poor habitats were used in preference to better ones. The individuals appeared to use some cues for settlement which did not fit site quality.

Natal site fidelity, breeding site fidelity and conspecific attraction have been suggested as important proximate cues for the nest site selection by the Osprey (Poole 1989; Lohmus 2001b; Schmidt and Wahl 2001; Wahl and Barbraud 2005; Schmidt et al. 2006). Usually, the proximate cues should have been evolutionarily tuned, so that the individuals may make a proper assessment of habitat and achieve greatest fitness (Stamps 2001). However, mismatch may occur as the conditions change. For the Osprey population studied, this change might arise from the increasing benefit of eutrophic lakes and the increasing acceptance of nesting on poles. These changes increased the quality of agricultural landscape as a breeding site, while site fidelity and conspecific attraction still drew the individuals to forest landscapes.

\section{Implications for conservation}

Together with the increasing acceptance of poles as nest sites, the Ospreys had greater access to eutrophic lakes, which meant they have benefitted from anthropogenic environmental change in the last decade. However, continuous monitoring is of particular importance for such a population with its shifting distribution patterns. On the one hand, the forest population as well as the tree nests should be monitored and supported by artificial platforms, as they could dwindle in the future. Secondly, the benefit of accessing to eutrophic lakes and open landscapes might not increase for ever. Breeding success accompanying future shifts should be monitored to check if such sites could become ecological traps for the Osprey.

\section{Zusammenfassung}

Verbreitungsmuster einer wachsenden Fischadler (Pandion haliaetus) Population in einer sich wandelnden Umwelt

Wir untersuchten die Nistplatzwahl und das Verbreitungsmuster der deutschen Fischadler Population auf Landschaftsebene. Dabei zeigten wir auf, wie man die Vorhersagen der ,ideal free distribution”-Theorie und ihrer Ableitungen anhand einer solchen wachsenden Population testen kann. Anfänglich bevorzugten Fischadler Landschaften mit einem höheren Anteil an Gewässern und an Waldgebieten. Nistplätze in solchen Landschaften wurden eher besiedelt und befanden sich in einer lokal höheren Siedlungsdichte. In dem Untersuchungszeitraum von 11 Jahren gab es jedoch einen graduellen Wandel der Nistplatzanteile mit einen abnehmenden Anteil von Nistplätzen im Wald und einem zunehmenden Anteil in landwirtschaftlich geprägten Gegenden. Während dieses Zeitraums nahm der Bruterfolg insgesamt zu und es gab keinen Unterschied zwischen dem Bruterfolg von Baumbrütern gegenüber Mastbrütern. Hingegen hatten diejenigen Paare einen höheren Bruterfolg an solchen Nistplätzen, die überwiegend von landwirtschaftlich genutzten Flächen und von weniger Waldanteilen umgeben waren. Der Grund für den höheren Bruterfolg lag sehr wahrscheinlich am effektiveren Beutefang in eutrophen Seen, die umgeben von landwirtschaftlichen Flächen liegen. Das Verbreitungsmuster der Fischadler stimmte nicht mit der Verteilung der untersuchten Ressourcen überein, was eine Abweichung von den getesteten Modellen darstellt. Als Interpretation dieser Ergebnisse schlugen wir vor, dass die proximaten Faktoren bei der Nistplatzwahl aufgrund anthropogen bedingter Veränderungen der Umwelt nicht mit der natürlichen Qualität von potenziellen Nistplätzen überein stimmte.

Acknowledgments This study was based on the enormous efforts of many nest guardians, ringers and coordinators. We deeply appreciate their enthusiasm for such long-term work. We are especially grateful to G. Dornbusch, S. Herold, G. Lohmann, P. Reuße, D. Roepke and P. Sömmer for providing and compiling data. We thank Landesamt fur Umwelt, Naturschutz und Geologie Mecklenburg-Vorpommern, Staatliche Vogelschutzwarte Brandenburg, Landesumweltamt Brandenburg, Landesamt für Umweltschutz Sachsen-Anhalt, Sächsisches Landesamt für Umwelt und Geologie, Staatliche Vogelschutzwarte Niedersachsen for providing the GIS layers of water bodies. We thank T. Hothorn for expert advice on the statistical analysis and R. Dennis as well as several anonymous reviewers for their valuable comments on the manuscript. This work was supported by the German Academic Exchange Service (DAAD) and the Deutsche Ornithologen-Gesellschaft (DO-G). The field work complied with relevant laws of Germany. 
Open Access This article is distributed under the terms of the Creative Commons Attribution Noncommercial License which permits any noncommercial use, distribution, and reproduction in any medium, provided the original author(s) and source are credited.

\section{References}

Abrahams MV (1986) Patch choice under perceptual constraints: a cause for departures from an ideal free distribution. Behav Ecol Sociobiol 19:409-415. doi:10.1007/BF00300543

Bunce A, Ward SJ, Norman FI (2005) Are age-related variations in breeding performance greatest when food availability is limited? J Zool 266:163-169. doi:10.1017/S0952836905006734

Ekholm P, Mitikka S (2006) Agricultural lakes in Finland: currentwater quality and trends. Environ Monit Assess 116:111-135. doi:10.1007/s10661-006-7231-3

Ewins PJ (1997) Osprey (Pandion haliaetus) populations in forested areas of North America: changes, their causes and management recommendations. J Raptor Res 31:138-150

Fernandez JM, Selma MAE, Aymerich FR, Saez MTP, Fructuoso MFC (2005) Aquatic birds as bioindicators of trophic changes and ecosystem deterioration in the Mar Menor lagoon (SE Spain). Hydrobiologia 550:221-235. doi:10.1007/s10750-005-4382-0

Flaxman SM, Reeve HK (2006) Putting competition strategies into ideal free distribution models: habitat selection as a tug of war. J Theor Biol 243:587-593. doi:10.1016/j.jtbi.2006.07.012

Fretwell SD (1972) Populations in a seasonal environment. Princeton University Press, Princeton

Fretwell SD, Lucas HL Jr (1970) On territorial behavior and other factors influencing habitat distribution in birds. Acta Biotheor 19:16-36. doi:10.1007/BF01601953

Krüger O, Lindström J (2001) Habitat heterogeneity affects population growth in goshawk Accipiter gentilis. J Anim Ecol 70:173181. doi:10.1046/j.1365-2656.2001.00481.x

Lohmus A (2001a) Habitat selection in a recovering Osprey Pandion haliaetus population. Ibis 143:651-657. doi:10.1111/j.1474919X.2001.tb04893.x

Lohmus A (2001b) Ospreys Pandion haliaetus in Estonia: a historical perpective. Vogelwelt 122:167-171

McPeek MA, Rodenhouse NL, Holmes RT, Sherry TW (2001) A general model of site-dependent population regulation: population-level regulation without individual-level interactions. Oikos 94:417-424. doi:10.1034/j.1600-0706.2001.940304.x

Mehner T, Diekmann M, Brämick U, Lemcke R (2005) Composition of fish communities in German lakes as related to lake morphology, trophic state, shore structure and human-use intensity. Freshw Biol 50:70-85. doi:10.1111/j.1365-2427. 2004.01294.x

Meyburg BU, Manowsky O, Meyburg C (1996) The osprey in Germany: its adaptation to environments altered by man. In: Bird DM (ed) Raptors in human landscapes. Academic Press, London, pp $125-135$

Morris DW (1987) Tests of density-dependent habitat selection in a patchy environment. Ecol Monogr 57:269-281. doi:10.2307/ 2937087

Morris DW (1988) Habitat-dependent population regulation and community structure. Evol Ecol 2:253-269. doi:10.1007/ BF02214286

Morris DW (2003) Toward an ecological synthesis: a case for habitat selection. Oecologia 136:1-13. doi:10.1007/s00442-003-1241-4

Odsjö T, Sondell J (2001) Population status and breeding success of Osprey Pandion haliaetus in Sweden, 1971-1998. Vogelwelt 122:155-166
Parker GA, Sutherland WJ (1986) Ideal free distribution when individuals differ in competitive ability: phenotype-limited ideal free distribution. Anim Behav 34:1222-1242. doi:10.1016/ S0003-3472(86)80182-8

Poole AF (1989) Osprey: a natural and unnatural history. Cambridge University Press, Cambridge

Pöysä H, Elmberg J, Sjöberg K, Nummi P (1998) Habitat selection rules in breeding mallards (Anas platyrhynchos): a test of two competing hypotheses. Oecologia 136:1-13

Pulliam HR, Danielson BJ (1991) Sources, sinks, and habitat selection: a landscape perspective on population dynamics. Am Nat 137:50-66. doi:10.1086/285139

Rodenhouse NL, Sherry TW, Holmes RT (1997) Site-dependent regulation of population size: a new synthesis. Ecology 94:20252042

SAS Institute (1999) SAS/STAT user's guide. Version 8, SAS Institute, Cary

Schindler DW, Dillon PJ, Schreier H (2006) A review of anthropogenic sources of nitrogen and their effects on Canadian aquatic ecosystems. Biogeochemistry 79:25-44. doi:10.1007/s10533-006-9001-2

Schmidt D (1995a) Zur ehemaligen Brutverbreitung des Fischadlers Pandion haliaetus in Westdeutschalnd. Vogelwelt 116:173-176

Schmidt D (1995b) Beringung nestjunger Fischadler Pandion haliaetus in Ostdeutschland mit Farbkennringen. Ber Vogelw Hiddensee 12:133-136

Schmidt D (1999) Untersuchungen zur Populationsbiologie und Habitatnutzung des Fischadlers Pandion haliaetus in Deutschland. ILN-Werkstattreihe 6, Singen

Schmidt D (2001) Die Bestandsentwicklung des Fischadlers Pandion haliaetus in Deutschland im ausgehenden 20. Jahrhundert. Vogelwelt 122:117-128

Schmidt D (2004) Fischadler (Pandion haliaetus). In: Gedeon K, Mitschke A, Sudfeldt C (eds) Brutvögel in Deutschland. Hohenstein-Ernstthal, pp 10-11

Schmidt D, Herold S, Lange H, Reusse P (2006) Zur Philopatrie des Fischadlers Pandion haliaetus in Deutschland-Zwischenergebnisse des Farbringprogramms 1995-2004. Populationsökol Greifvogel Eulenarten 5:133-142

Schmidt D, Wahl R (2001) Horst- und Partnertreue des Fischadlers Pandion haliaetus in Ostdeutschalnd und Zentralfrankreich. Vogelwelt 122:129-140

Sergio F, Blas J, Forero MG, Donazar JA, Hiraldo F (2007) Sequential settlement and site dependence in a migratory raptor. Behav Ecol 18:811-821. doi:10.1093/beheco/arm052

Solonen T (2008) Large-scale climatic phenomena and timing of breeding in a local population of the Osprey Pandion haliaetus in southern Finland. J Ornithol 149:229-235. doi:10.1007/ s10336-007-0264-8

Soutullo A, Liminana R, Urios V, Surroca M, Gill JA (2006) Densitydependent regulation of population size in colonial breeders: allee and buffer effects in the migratory Montagu's harrier. Oecologia 149:543-552. doi:10.1007/s00442-006-0465-5

Stamps JA (2001) Habitat selection by dispersers: integrating proximate and ultimate approaches. In: Clobert J, Danchin E, Dhondt AA, Nichols JD (eds) Dispersal. Oxford University Press, New York, pp 230-242

Suter W (1995) Are Cormorants Phalacrocorax carbo wintering in Switzerland approaching carrying capacity? An analysis of increase patterns and habitat choice. Ardea 83:255-266

Umweltbundesamt (2004) CORINE Land Cover. DLR-DFD

Wahl R, Barbraud C (2005) Osprey Pandion haliaetus: population dynamics and conservation of in central France. Alauda 73:365-373

Weber M, Schmidt D, Hädrich J (2003) Chlororganische Rückstände in Eiern des Fischadlers (Pandion haliaetus) aus Deutschland. J Ornithol 144:45-58. doi:10.1007/BF02465516 